\title{
FORMULASI TEPUNG KECAMBAH KEDELAI DAN TEPUNG IKAN TUNA SEBAGAI BAHAN MP-ASI BUBUK INSTAN UNTUK BAYI USIA 6 - 8 BULAN
}

Oleh :

MAHARANY TRIASTUTI J*), RINDIANI, dan AGUSTINA E.W.**)

\begin{abstract}
ABSTRAK
Makanan Pendamping Air Susu Ibu (MP-ASI) adalah makanan atau minuman yang diberikan pada bayi atau anak usia 6-24 bulan guna memenuhi kebutuhan gizi selain dari Air Susu Ibu. Pada umur 6-8 bulan asupan energi dari ASI yaitu $437 \mathrm{Kal} / \mathrm{hari}$, sedangkan yang dianjurkan $783 \mathrm{Kal}$, jadi energi yang dibutuhkan dari MP-ASI yaitu $346 \mathrm{Kal} / \mathrm{hari}$. Salah satu upaya yang diharapkan dapat membantu meningkatkan mutu gizi yang ada dalam MP-ASI adalah dengan menggunakan tepung kecambah kedelai dan tepung ikan tuna.

Metode yang digunakan dalam penelitian ini adalah Rancangan Acak Lengkap (RAL) menggunakan faktor tunggal yaitu formulasi tepung kecambah kedelai dan tepung ikan tuna (F) yang terdiri dari delapan perlakuan yaitu F1 (15\%:85\%), F2 (25\%:75\%), F3 (35\%:65\%), F4 (45\%:55\%), F5 (55\%:45\%, F6 (65\%:35\%), F7 (75\%:25\%), dan F8 (85\%:15\%).

Hasil penelitian menunjukkan bahwa semakin besar proporsi tepung kecambah kedelai maka kadar abu, lemak dan nilai energi semakin meningkat, sedangkan semakin tinggi proporsi tepung ikan tuna maka kadar protein dalam formula MP-ASI juga semakin meningkat secara signifikan. Berdasarkan hasil analisa kandungan gizi dan nilai energi dapat disimpulkan bahwa MP-ASI Bubuk Instan dengan proporsi F1 (15\%:85\%), F2 (25\%:75\%), F3 (35\%:65\%), F4 (45\%:55\%), F5 (55\%:45\%) dan F6 (65\%:35\%) merupakan MP-ASI Bubuk Instan yang memenuhi persyaratan MP-ASI diantara delapan formulasi yang ada.
\end{abstract}

Kata Kunci : MP-ASI Bubuk Instan, Tepung Kecambah Kedelai, Tepung Ikan Tuna, Formulasi. 


\section{PENDAHULUAN}

Salah satu masalah pokok kesehatan yang ada di negara berkembang adalah masalah gangguan kesehatan yang disebabkan oleh kekurangan gizi. Di Indonesia masih terdapat beberapa masalah gizi, salah satu diantaranya adalah KEP atau kurang energi protein (Pratomo dkk. dalam Fahriyani, 2011).

Hasil Riset Kesehatan Nasional 2010 dalam Sofiani (2011), melaporkan bahwa prevalensi gizi buruk di Indonesia dalam kurun waktu antara tahun 2007-2010 penurunan gizi buruk sangat lambat atau terjadi penurunan hanya 0,5\% dari 5,4\% di tahun 2007 turun menjadi 4,9\% di tahun 2010. Angka itu belum merata di semua daerah, masih ada beberapa kawasan yang mengalami gizi buruk.

Makanan Pendamping Air Susu Ibu (MP-ASI) adalah makanan atau minuman yang mengandung zat gizi, diberikan pada bayi atau anak usia 6-24 bulan guna memenuhi kebutuhan gizi selain dari air susu ibu (DEPKES RI, 2006). Tahapan tumbuh kembang bayi menurut nutrisi dibagi menjadi empat, yaitu Tahap I (mulai 6 bulan), Tahap II (6-8 bulan), Tahap III (8-12 bulan) dan Tahap Junior (1-3 tahun). Pada bayi usia 6-8 bulan mulai diperkenalkan makanan bentuk bubur dengan dengan rasa makanan yang bervariasi (Nestle Indonesia, dalam Hayati, 2003). Bayi usia 6-8 bulan membutuhkan energy sebesar $783 \mathrm{kal} / \mathrm{hari}$. Sedangkan asupan energi dari ASI sebesar $437 \mathrm{kal} / \mathrm{hari}$, sehingga energi yang didapatkan dari MP-ASI adalah sebesar 346 kal/hari (Soenardi dalam Saloko, 2009)

Kedelai dalam bentuk kecambah mempunyai vitamin lebih banyak dibandingkan dengan bentuk biji (Gunawan, 2009). Pada saat perkecambahan, terjadi hidrolisis karbohidrat, protein, dan lemak menjadi senyawa yang lebih sederhana, sehingga mudah dicerna (Astawan, 2010).

\section{TINJAUAN PUSTAKA}

\section{Kecambah Kedelai}

Kedelai merupakan bahan makanan sumber protein nabati yang banyak mengandung zat gizi. Meskipun demikian kedelai juga memiliki kelemahan yaitu mengandung antigizi, antara lain antitripsin, hemaglutinin atau lektin, oligosakarida, dan asam fitat. Salah satu upaya untuk menginaktifkan zat-zat antigizi tersebut adalah dengan mengolah kedelai menjadi kecambah kedelai (Astawan, 2004).

Menurut Prangdimurti dalam Sofiani (2011), perkecambahan merupakan suatu proses keluarnya bakal tanaman (tunas) dari lembaga yang disertai dengan terjadinya mobilisasi cadangan makanan dari jaringan penyimpanan makanan atau keping biji ke bagian vegetatif. Dalam perkecambahan terjadi perombakan komponen kompleks dari biji menjadi komponen yang lebih sederhana yang diperlukan untuk menunjang pertumbuhan kedelai menjadi tunas dan tanaman nantinya.

Adanya glukosa dan fruktosa menyebabkan kecambah terasa enak dan manis. Protein dari sel-sel penyimpanan akan dirombak oleh sekumpulan enzim proteolitik untuk menghasilkan suatu campuran asam amino bebas yang lebih mudah diserap dan digunakan tubuh (Astawan dalam Sofiani, 2011).

Tabel 1. Kandungan Asam Amino Esensial Kecambah Kedelai Per 1 GramProtein

\begin{tabular}{|l|c|}
\hline \multicolumn{1}{|c|}{ Asam amino esensial } & Kandungan $(\mathrm{mg})$ \\
\hline Isoleusin & 36,3 \\
Leusin & 42,7 \\
Lisin & 34,0 \\
Metionin & 7,3 \\
Sistin & 4,1 \\
Total AAS & 11,4 \\
Fenilalanin & 30,0 \\
Tirosin & 32,9 \\
Total AAA & 62,9 \\
Treonin & 25,6 \\
Triptofan & 25,0 \\
Valin & 36,3 \\
\hline
\end{tabular}

Sumber : Hardinsyah dan Martianto (1992) 


\section{Tepung Kecambah Kedelai}

Meskipun potensi kecambah kedelai cukup besar, tetapi daya tahan simpannya sangat rendah sehingga perlu adanya upaya pengawetan untuk memperbesar daya gunanya. Salah satu cara yang dapat dilakukan adalah dengan cara pembuatan tepung kecambah kedelai.

Hasil analisa komposisi kimia tepung kedelai dan tepung kecambah kedelai dapat dilihat pada Tabel 2 dan Tabel 3.

Tabel 2. Hasil Analisa Komposisi Kimia Tepung Kedelai

\begin{tabular}{|l|c|}
\hline \multicolumn{1}{|c|}{ Komponen } & Kadar (g) \\
\hline Air & 6,89 \\
Abu & 1,76 \\
Protein & 41,37 \\
Lemak & 22,69 \\
Serat Kasar & 5,96 \\
\hline
\end{tabular}

Sumber : Astuti dalam Farhan (2003)

Tabel 3. Hasil Analisa Komposisi Kimia Tepung Kecambah Kedelai

\begin{tabular}{|l|c|}
\hline \multicolumn{1}{|c|}{ Komponen } & Kadar \\
\hline Air $(\%$ bk) & 4,59 \\
Abu $(\%$ bk) & 4,21 \\
Protein $(\%$ bk) & 40,49 \\
Lemak $(\%$ bk) & 24,09 \\
Karbohidrat $(\%$ bk) & 26,62 \\
Asam folat $(\mu \mathrm{g} / 100 \mathrm{~g})$ & - \\
ALTJ $(\%)$ & - \\
Kalori $(K k a l / 100 \mathrm{~g})$ & 419,65 \\
\hline
\end{tabular}

Keterangan : - Tidak dianalisis

Sumber : Pangestuti., $d k k$ (2004)

Makanan Pendamping Air Susu Ibu (MPASI)

Makanan pendamping air susu ibu (MPASI) adalah makanan bergizi yang diberikan disamping ASI kepada bayi berusia enam bulan ke atas atau berdasarkan indikasi medik, sampai anak berusia 24 bulan untuk mencapai kecukupan gizi. MP-ASI bubuk instan adalah MP-ASI yang telah diolah sehingga dapat disajikan seketika dengan hanya menambahkan air minum atau cairan lain yang sesuai (Badan Standarisasi Nasional, 2005).

Persyaratan MP-ASI adalah memenuhi jumlah zat gizi yang diperlukan bayi yaitu nilai energi dan protein yang tinggi, mengandung vitamin dan mineral yang yang cukup, dapat diterima dengan baik, harga relatif murah dan sebaiknya dapat diproduksi dari bahan-bahan yang tersedia secara lokal (Fahriyani, 2011).

MP-ASI untuk bayi harus menghasilkan energi.

Syarat mutu MP-ASI adalah zat gizi yang dikandung MP-ASI harus memenuhi kebutuhan gizi pada kelompok umur sasaran. Persyaratan MP-ASI Bubuk Instan yang tercantum dalam KEPMENKES RI nomor 224/Menkes/SK/II/2007 dapat dilihat pada Tabel 6.

Tabel 6. Spesifikasi Teknis Makanan Pendamping Air Susu Ibu (MP-ASI) 
Bubuk Instan untuk Bayi 6-12 Bulan

\begin{tabular}{|c|c|c|c|}
\hline No & Zat Gizi & Satuan & Kadar \\
\hline 1 & Energi & Kal & $400-440$ \\
\hline 2 & $\begin{array}{l}\text { Protein (kualitas protein tidak kurang dari } 70 \% \text { kualitas } \\
\text { kasein) }\end{array}$ & $\mathrm{g}$ & $15-22$ \\
\hline 3 & Lemak (kadar asam linoleat minimal $300 \mathrm{mg}$ per & g & $10-15$ \\
\hline & $100 \mathrm{Kal}$ atau 1,4 gram per 100 gram produk) & & \\
\hline & Karbohidrat & & \\
\hline & 4.1 Gula (sukrosa) & & \\
\hline 4 & 4.2 Serat & & \\
\hline & Vitamin A & $\mathrm{g}$ & maksimum 30 \\
\hline & Vitamin D & $\mathrm{g}$ & maksimum 5 \\
\hline 5 & Vitamin E & RE & $250-350$ \\
\hline 6 & Vitamin $\mathrm{K}$ & $\mathrm{mcg}$ & $7-10$ \\
\hline 7 & Thiamin & $\mathrm{mg}$ & $4-6$ \\
\hline 8 & Riboflavin & $\mathrm{mcg}$ & $7-10$ \\
\hline 9 & Niasin & $\mathrm{mg}$ & $0,3-0,4$ \\
\hline 10 & Vitamin $B_{12}$ & $\mathrm{mg}$ & $0,3-0,5$ \\
\hline 11 & Asam folat & $\mathrm{mg}$ & $2,5-4,0$ \\
\hline 12 & Vitamin $B_{6}$ & $\mathrm{mg}$ & $0,3-0,6$ \\
\hline 13 & Asam Pantotenat & $\mathrm{mcg}$ & $40-100$ \\
\hline 14 & Vitamin C & $\mathrm{mg}$ & $0,4-0,7$ \\
\hline 15 & Besi & $\mathrm{mg}$ & $1,3-2,1$ \\
\hline 16 & Kalsium & $\mathrm{mg}$ & $27-35$ \\
\hline 17 & Natrium & $\mathrm{mg}$ & $5-8$ \\
\hline 18 & Seng & $\mathrm{mg}$ & $200-400$ \\
\hline 19 & Iodium & $\mathrm{mg}$ & $240-400$ \\
\hline 20 & Fosfor & $\mathrm{mg}$ & $2,5-4,0$ \\
\hline 21 & & $\mathrm{mcg}$ & $45-70$ \\
\hline 22 & Selenium & $\mathrm{mg}$ & perbandingan \\
\hline & Air & & $\mathrm{Ca}: \mathrm{P}=1,2-2,0$ \\
\hline 23 & & $\mathrm{mcg}$ & $10-15$ \\
\hline 24 & & $\mathrm{~g}$ & maksimal 4 \\
\hline
\end{tabular}

\section{METODE PENELITIAN}

Penelitian dilakukan di Laboratorium Analisis Pangan Politeknik Negeri Jember pada bulan Mei - Juli 2013. Alat yang digunakan meliputi timbangan analitis, kompor, dehydrator, cold storage, penggiling tepung, ayakan 60 mesh, alat pengepres, pengaduk kayu, dehydrator, cold storage, penggiling tepung, blender, dan ayakan 60 mesh. Sedangkan alat untuk analisa formula MP-ASI
Bubuk Instan adalah oven, timbangan analitis, desikator, tanur pengabuan, penangas air, tabung destilasi, kondensor, erlenmeyer, bunsen, eksikator, labu kjedahl, labu lemak, alat ekstraksi Soxhlet, labu ukur, spatula, sudip, cawan porselin, botol timbang, mortar, spatula, corong gelas, gelas piala, buret, gelas ukur, pipet ukur, pipet tetes, tang penjepit, kertas saring, dan alat tulis.

Sampel yang akan digunakan adalah formulasi makanan pendamping ASI Bubuk Instan dengan menggunakan tepung kecambah 
kedelai dan tepung ikan tuna yang berjumlah 24 satuan percobaan (sampel) formula MPASI. Pada penentuan perlakuan terdapat 9 formulasi yang diusulkan dengan masingmasing perbandingan prosentase, yaitu F1 $(15 \%: 85 \%), \mathrm{F} 2$ (25\% : $75 \%), \mathrm{F} 3$ (35\%: $65 \%), \mathrm{F} 4(45 \%: 55 \%), \mathrm{F} 5(55 \%: 45 \%, \mathrm{~F} 6$ $(65 \%: 35 \%), \mathrm{F} 7$ (75\% : $25 \%), \mathrm{F} 8(85 \%$ : $15 \%)$.
Rancangan penelitian menggunakan Rancangan Acak Lengkap (RAL) yang terdiri atas 8 taraf perlakuan dan 3 kali pengulangan (Hanafiah, 2005). Masing-masing taraf perlakuan dilakukan 3 kali pengulangan/replikasi. Rancangan penelitian disajikan pada Tabel 7.

Tabel 7. Rancangan Acak Lengkap

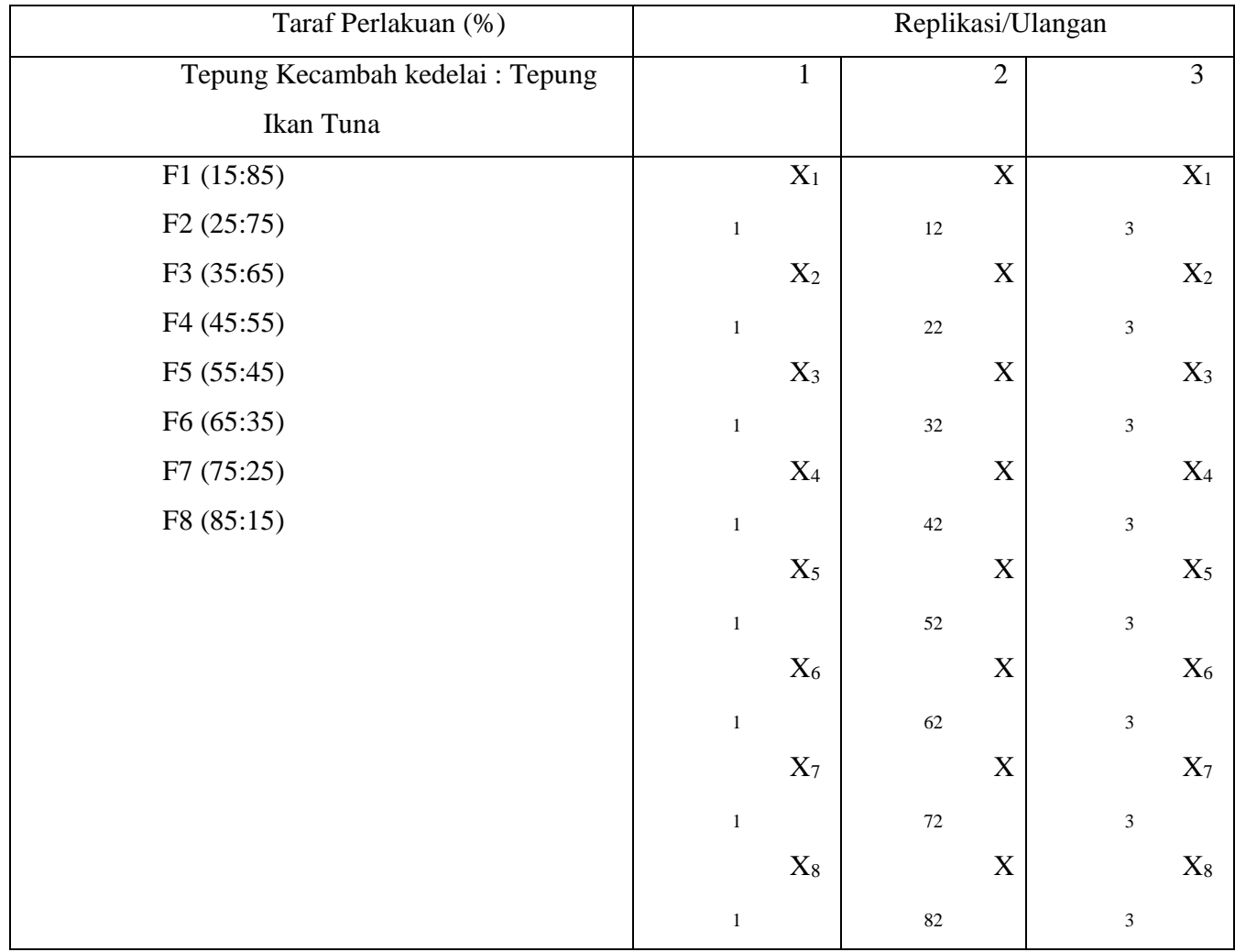

Keterangan:

$\mathrm{X}_{11}, \mathrm{X}_{12}, \mathrm{X}_{13}, \ldots \ldots . ., \mathrm{X}_{83}$ : Unit Penelitian

\section{Pengumpulan Data}

Setiap perlakuan formulasi MP-ASI Bubuk Instan tepung kecambah kedelai dan tepung ikan tuna dilakukan perhitungan kandungan gizi yang meliputi kadar air dengan metode oven, kadar karbohidrat metode by difference, kadar sukrosa metode Luff-schoorl, kadar protein metode semi-mikro kjeldahl dan kadar lemak metode soxhlet. Setelah itu menghitung nilai energi yang diketahui dari

HASIL DAN PEMBAHASAN

Deskripsi MP-ASI Instan komposisi pembuatan formula pada tiap-tiap perlakuan.

Hasil uji kandungan gizi dan nilai energi formulasi MP-ASI akan dibandingkan dengan kandungan zat gizi dan nilai energi yang telah ditetapkan sesuai dengan persyaratan KEPMENKES RI Nomor 224/Menkes/SK/II/2007 tentang spesifikasi teknis MP-ASI.

MP-ASI Bubuk Instan adalah MPASI yang telah diolah sehingga dapat disajikan seketika dengan hanya penambahan air minum 
atau cairan lain yang sesuai (Badan Standarisasi Nasional, 2005). Produk MP-ASI yang dihasilkan dalam penelitian ini berbentuk serbuk dengan warna coklat kekuningan. MPASI Bubuk Instan juga memiliki aroma langu dan amis. Aroma langu tersebut diduga berasal dari tepung kecambah kedelai (Dewi, 2008).

Rasa MP-ASI Bubuk Instan secara keseluruhan adalah manis. Hal ini disebabkan karena kandungan gula MP-ASI Bubuk Instan sebesar $15 \%$ per seratus gram bahan. Rasa manis dan gurih juga dipengaruhi dari penambahan susu skim yaitu sebesar $25 \%$ per seratus gram bahan (Sofiani, 2011).

\section{Analisa Kandungan Gizi}

Analisa yang dilakukan meliputi analisa kadar air metode oven, kadar abu metode tanur, kadar protein metode Semi Mikro-Kjedahl, kadar lemak metode soxhlet, dan perhitungan kadar karbohidrat by difference.

\begin{tabular}{|c|c|c|c|c|c|c|c|c|c|}
\hline \multirow{2}{*}{$\begin{array}{c}\text { Parame } \\
\text { ter }\end{array}$} & \multicolumn{8}{|c|}{ Formula } & \multirow[t]{2}{*}{ KEPMENKES RI } \\
\hline & $\mathrm{F} 1$ & $\mathrm{~F} 2$ & F3 & F4 & F5 & F6 & F7 & F8 & \\
\hline $\begin{array}{l}\text { Kadar } \\
\text { Air (g) }\end{array}$ & 1,75 & 1,55 & 1,65 & 1,80 & 2,01 & 1,66 & 2,09 & 1,95 & $\leq 4$ \\
\hline $\begin{array}{l}\text { Kadar } \\
\text { Abu } \\
\text { (g) }\end{array}$ & 0,64 & 0,69 & 0,71 & 0,73 & 0,79 & 0,86 & 0,92 & 0,97 & - \\
\hline $\begin{array}{l}\text { Kadar } \\
\text { Protein } \\
\text { (g) }\end{array}$ & $\begin{array}{c}19,7 \\
1\end{array}$ & 18,74 & 17,86 & $\begin{array}{c}16,7 \\
0\end{array}$ & 15,98 & $\begin{array}{c}15,7 \\
0\end{array}$ & 14,76 & 14,04 & $15-22$ \\
\hline $\begin{array}{l}\text { Kadar } \\
\text { Lemak } \\
(\mathrm{g})\end{array}$ & 8,29 & 9,43 & 10,15 & $\begin{array}{c}10,5 \\
2\end{array}$ & 10,84 & $\begin{array}{c}11,0 \\
8\end{array}$ & 11,81 & 12,16 & $10-15$ \\
\hline $\begin{array}{l}\text { Kadar } \\
\text { Karboh } \\
\text { idrat } \\
\text { (g) }\end{array}$ & $\begin{array}{c}69,5 \\
9\end{array}$ & 69,57 & 69,62 & $\begin{array}{c}70,2 \\
4\end{array}$ & 70,36 & $\begin{array}{c}70,6 \\
8\end{array}$ & 70,41 & 70,88 & - \\
\hline $\begin{array}{l}\text { Kadar } \\
\text { Sukros } \\
\text { a (g) }\end{array}$ & $\begin{array}{c}10,4 \\
5\end{array}$ & 10,80 & 11,78 & $\begin{array}{c}12,0 \\
5\end{array}$ & 12,38 & $\begin{array}{c}12,6 \\
8\end{array}$ & 12,79 & 12,76 & $\leq 30$ \\
\hline $\begin{array}{l}\text { Nilai } \\
\text { Energi } \\
(\mathrm{kkal})\end{array}$ & $\begin{array}{l}431, \\
87\end{array}$ & 438,18 & 441,31 & $\begin{array}{l}42, \\
43\end{array}$ & 443,01 & $\begin{array}{l}45, \\
34\end{array}$ & 446,99 & 449,13 & $400-440$ \\
\hline
\end{tabular}

Keterangan:

F1 $\quad=$ Tepung Kecambah kedelai : Tepung Ikan Tuna $=15 \%: 85 \%$

F2 $\quad=$ Tepung Kecambah kedelai : Tepung Ikan Tuna $=25 \%: 75 \%$

F3 $=$ Tepung Kecambah kedelai : Tepung Ikan Tuna $=35 \%: 65 \%$

F4 $\quad=$ Tepung Kecambah kedelai : Tepung Ikan Tuna $=45 \%: 55 \%$

F5 $\quad=$ Tepung Kecambah kedelai : Tepung Ikan Tuna $=55 \%: 45 \%$

F6 $\quad=$ Tepung Kecambah kedelai : Tepung Ikan Tuna $=65 \%: 35 \%$

F7 $\quad=$ Tepung Kecambah kedelai : Tepung Ikan Tuna $=75 \%: 25 \%$

F8 $\quad=$ Tepung Kecambah kedelai : Tepung Ikan Tuna $=85 \%: 15 \%$

\section{Kadar Air}

Kadar air MP-ASI Bubuk Instan berkisar antara 1,55 - 2,09 g/100 g. Kadar air yang paling rendah adalah kadar air pada formula F2 (1,55 g) dan yang tertinggi adalah pada formula F7 $(2,09$ g). 
Berikut adalah nilai rata-rata kadar air MP-ASI ikan tuna dapat dilihat pada Gambar 4. Bubuk Instan tepung kecambah kedelai dan tepung

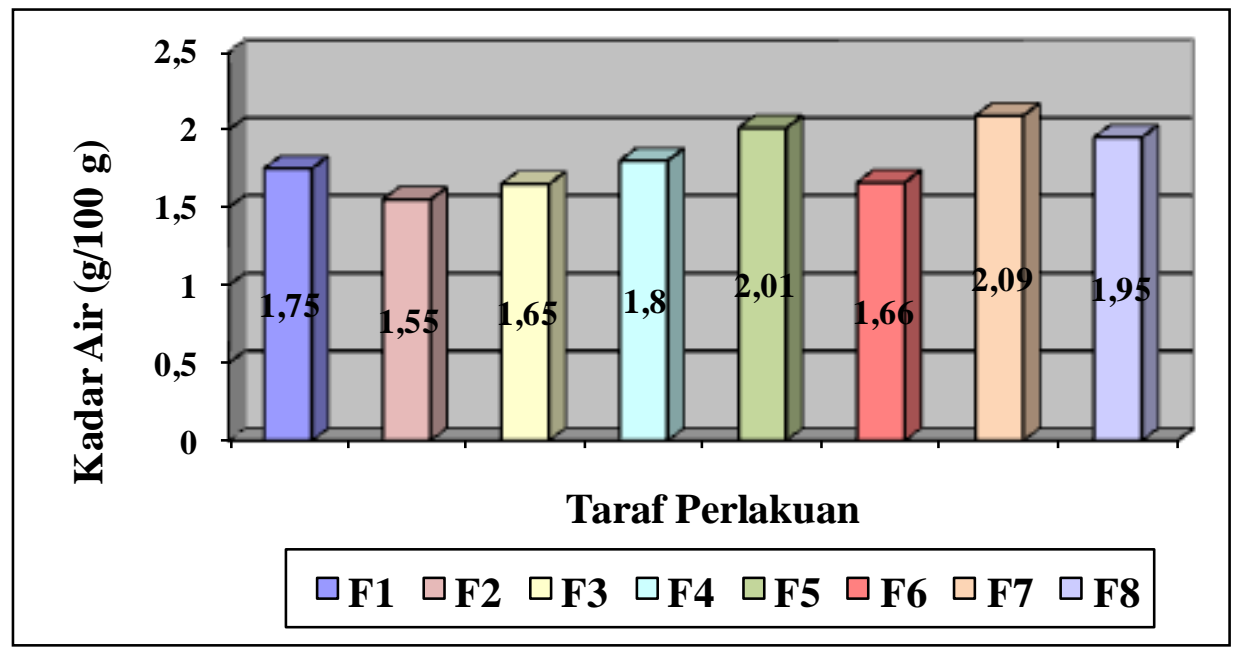

Gambar 4. Diagram Batang Kadar Air MP-ASI Bubuk Instan Tepung

Kecambah Kedelai Dan Tepung Ikan Tuna

Data kadar air MP-ASI Bubuk Instan tidak terdistribusi normal, sehingga diuji dengan analisis statistik Kruskal Wallis dengan tingkat kepercayaan 95\%. Hasil analisis statistik Kruskal Wallis menunjukkan bahwa proporsi tepung kecambah kedelai memberikan pengaruh yang tidak signifikan $(\mathrm{p}=0,119)$ terhadap kadar air MP-ASI Bubuk Instan. Hal ini berarti kadar air MP-ASI Bubuk Instan tiap taraf perlakuan relatif sama.

Kadar air yang yang disyaratkan dalam KEPMENKES RI nomor 224/Menkes/SK/II/2007 tentang spesifikasi teknis Makanan Pendamping ASI adalah maksimal 4 g/100 g MP-ASI. Berdasarkan hasil analisis, maka kadar air dari semua taraf perlakuan mulai dari formula F1-F8 memenuhi persyaratan tersebut. Kadar air MP-ASI relatif kecil, sehingga produk bersifat higroskopis (mudah menyerap air).

\section{Kadar Abu}

Kadar abu MP-ASI Bubuk Instan berkisar antara 0,64 - 0,97 g/100 g. Kadar abu terendah adalah pada formula $\mathrm{F} 1$, yaitu $0,64 \mathrm{~g}$, sedangkan kadar abu tertinggi adalah pada formula F8, yaitu $0,976 \mathrm{~g}$.

Berikut adalah nilai rata-rata kadar abu MP-ASI Bubuk Instan dapat dilihat pada Gambar 5.

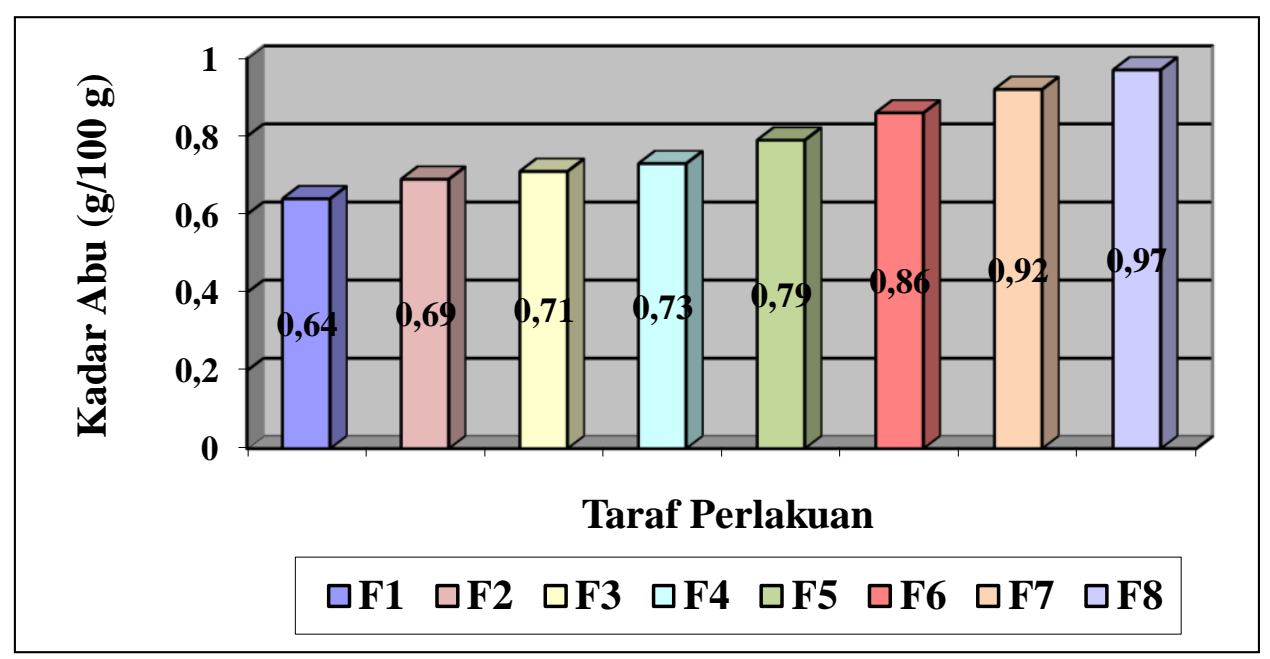


Data kadar abu MP-ASI Bubuk Instan tidak terdistribusi normal (sign $<0,05)$ sehingga diuji dengan analisis statistik Kruskal Wallis dengan tingkat kepercayaan 95\%. Hasil analisis statistik Kruskal Wallis menunjukkan bahwa proporsi tepung kecambah kedelai memberikan pengaruh yang signifikan $(\mathrm{p}=$ 0,004) terhadap kadar abu MP-ASI Bubuk Instan. Hal ini berarti kadar abu MP-ASI Bubuk Instan tiap taraf perlakuan relatif berbeda.

\section{Kadar Protein}

Kadar Protein MP-ASI Bubuk Instan berkisar antara 14,04 - 19,71 g/100 g. Formulasi yang memenuhi persyaratan kadar protein yang tercantum dalam KEPMENKES RI nomor 224/Menkes/SK/II/2007 tentang spesifikasi teknis MP-ASI, yaitu 15-22 g/100 g MP-ASI. Formula F8 memiliki kadar protein paling rendah, yaitu
Hasil uji Mann-Whitney dengan tingkat kepercayaan 95\% menunjukkan bahwa kadar abu MP-ASI Bubuk Instan formula F1, F2, F3, F4 terhadap perlakuan formula F5-F8 berbeda secara signifikan. Kadar abu pada perlakuan formula F5 terhadap perlakuan formula F6-F8 berbeda secara Signifikan. Selain itu kadar abu pada formula F6 dan F7 terhadap formula F8 berbeda secara signifikan. Hal ini berarti kadar abu MP-ASI Bubuk Instan yang berbeda secara signifikan yaitu pada formula F8.

14,04 g dan formula F1 memiliki kadar protein yang paling tinggi, yaitu 19,71 g.

Berikut adalah nilai rata-rata kadar protein MP-ASI Bubuk Instan tepung kecambah kedelai dan tepung ikan tuna dapat dilihat pada Gambar 6 .

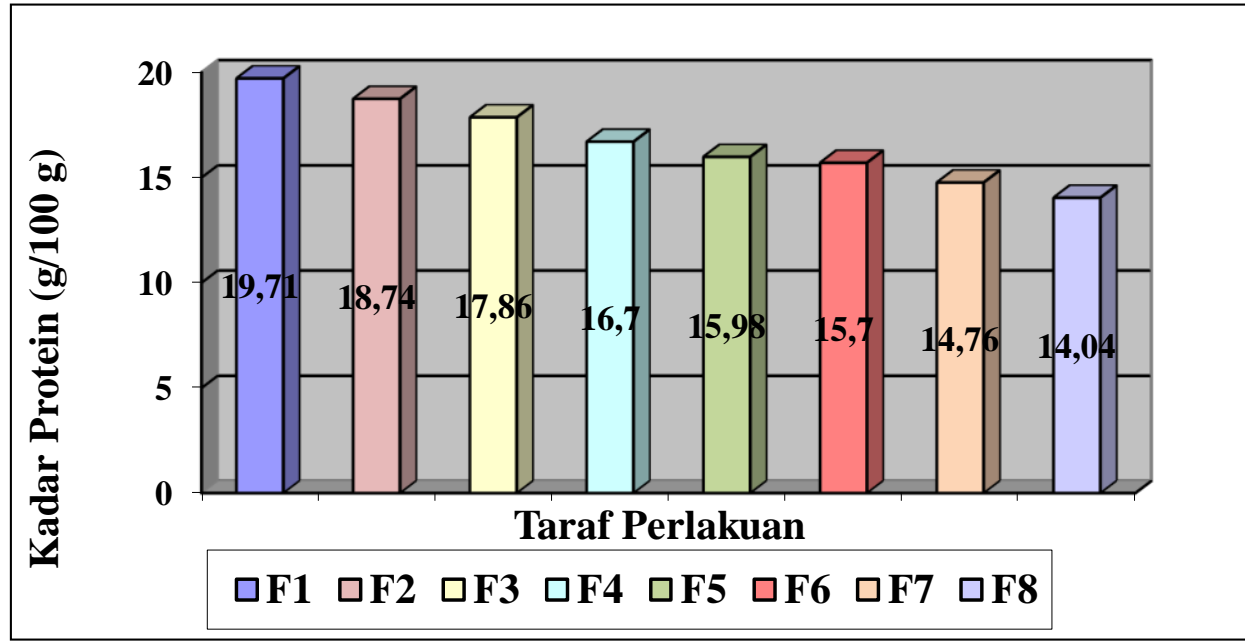

Gambar 6. Diagram Batang Kadar Protein MP-ASI Bubuk InstanTepung Kecambah Kedelai Dan Tepung Ikan Tuna

Hasil penelitian menunjukkan bahwa semakin tinggi proporsi tepung ikan tuna maka kadar protein MP-ASI Bubuk Instan semakin meningkat. Pada uji normalitas menunjukkan bahwa kadar protein MP-ASI Bubuk Instan terdistribusi normal (sign > 0,05) sehingga dapat diuji dengan analisis statistik One Way Anova (Sidik Ragam) pada tingkat kepercayaan 95\%. Hasil analisis statistik Sidik Ragam pada tingkat kepercayaan $95 \% \quad(\alpha=0,05)$ menunjukkan bahwa kadar potein pada tiaptiap taraf perlakuan memberikan perbedaan yang signifikan $(\mathrm{p}=0.000)$ terhadap kadar protein MP-ASI Bubuk Instan. Hal ini berarti kadar protein MP-ASI Bubuk Instan tiap taraf perlakuan relatif berbeda.

Dalam formulasi MP-ASI Bubuk Instan, kontribusi protein terbesar berasal dari susu skim. Tepung ikan tuna ditambahkan dengan tujuan untuk menambah nilai protein dari MP-ASI Bubuk Instan. Jumlah susu skim pada setiap formula disamakan, yang membedakannya adalah jumlah tepung kecambah kacang kedelai dan tepung ikan tuna. 
Hal ini dilakukan untuk melihat pengaruh kadar protein pada tiap-tiap formulasi MP-ASI Bubuk Instan. Penggunaan tepung kecambah

\section{Kadar Lemak}

Kadar lemak semua taraf perlakuan pada MP-ASI Bubuk Instan telah memenuhi kadar lemak menurut persyaratan KEPMENKES RI nomor 224/Menkes/SK/II/2007 tentang spesifikasi teknis MP-ASI yaitu $10-15 \mathrm{~g} / 100 \mathrm{~g}$. Dari beberapa taraf perlakuan formulasi hanya ada 6 formula yang memenuhi persyaratan yaitu formula F3, F4, F5, F6, F7 dan F8, kecuali MPASI Bubuk Instran pada taraf perlakuan kedelai dan tepung ikan tuna dilakukan untuk menambah nilai protein dari MP-ASI Bubuk Instan. formula FI dengan proporsi tepung kecambah kedelai $15 \%$ dan formula F2 dengan proporsi tepung kecambah kedelai 25\%. Hal ini disebabkan karena kadar lemak masih kurang dari $10 \mathrm{~g} / 100 \mathrm{~g}(8,29 \mathrm{~g} / 100 \mathrm{~g}$ dan 9,43 g/100 g).

Berikut adalah nilai rata-rata kadar lemak MP-ASI Bubuk Instan tepung kecambah kedelai dan tepung ikan tuna dapat dilihat pada Gambar

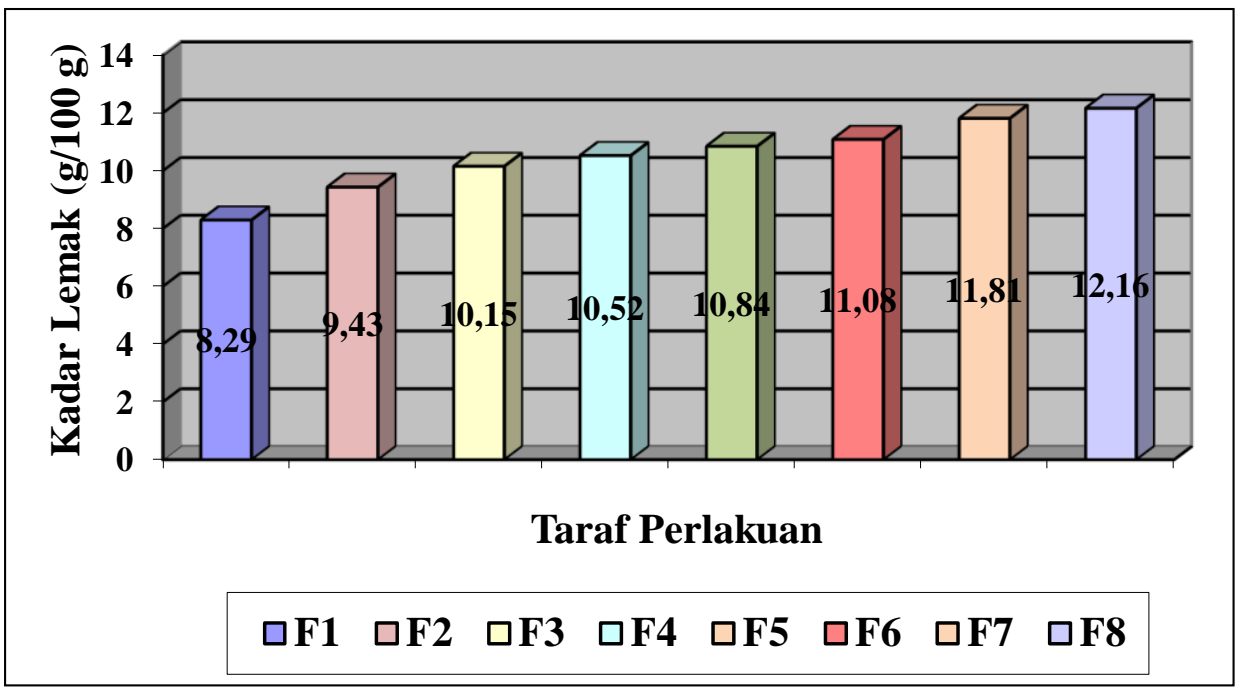

Gambar 7. Diagram Batang Kadar Lemak MP-ASI Bubuk Instan Tepung Kecambah Kedelai Dan Tepung Ikan Tuna

Pada uji normalitas menunjukkan bahwa kadar lemak MP-ASI Bubuk Instan terdistribusi normal ( ign $>0,05$ ) sehingga diuji dengan analisis statistik One Way Anova (Sidik Ragam) pada tingkat kepercayaan 95\%. Hasil analisis statistik Sidik Ragam pada tingkat kepercayaan 95\% $(\alpha=$ $0,05)$ menunjukkan bahwa kadar lemak pada tiaptiap taraf perlakuan memberikan perbedaan yang signifikan $(\mathrm{p}=0.000)$ terhadap kadar lemak MPASI. Hal ini berarti kadar lemak MP-ASI Bubuk Instan tiap taraf perlakuan relatif berbeda.

\section{Kadar Karbohidrat}

Kadar karbohidrat MP-ASI Bubuk Instan berkisar antara 69,59 - 70,88 g/100 g. Semakin tinggi nilai seluruh atau salah satu dari kadar air, abu, protein, dan lemak maka kadar karbohidrat akan menjadi lebih rendah. Kadar karbohidrat tertinggi, yaitu $70,88 \mathrm{~g}$ terdapat pada taraf perlakuan formula F8 dan formula F2 memiliki kadar karbohidrat terendah yaitu sebesar 69,59 g. Pada Formula F8, kadar protein formula tersebut adalah terendah diantara yang lain yaitu 14,04 g/100 g. Hal ini dapat menjadi penyebab tingginya kadar karbohidrat tertinggi. yang diperoleh melalui perhitungan by difference. Berikut adalah nilai rata-rata kadar karbohidrat MP-ASI Bubuk Instan 



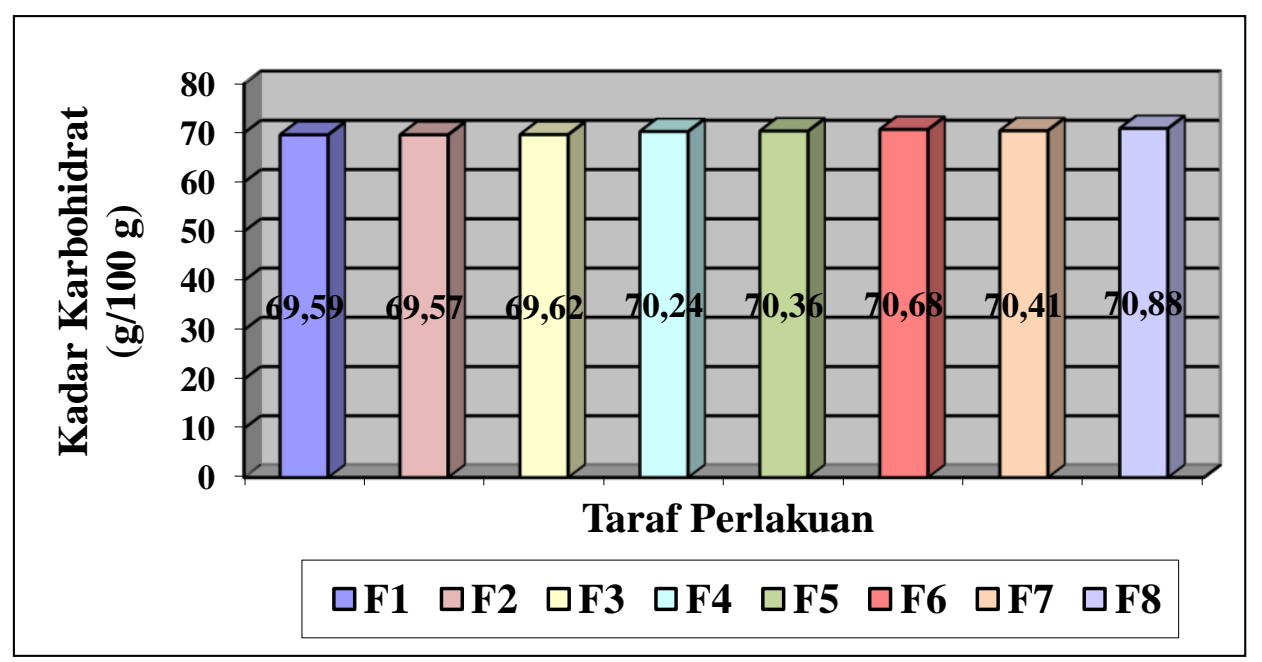

Gambar 8. Diagram Batang Kadar Karbohidrat MP-ASI Bubuk Instan Tepung Kecambah Kedelai Dan Tepung Ikan Tuna

Pada uji normalitas menunjukkan bahwa

kadar Karbohidrat MP-ASI Bubuk Instan terdistribusi normal ( $\operatorname{sign}>0,05$ ) sehingga diuji dengan analisis statistik One Way Anova (Sidik Ragam) pada tingkat kepercayaan 95\%. Hasil analisis statistik Sidik Ragam pada tingkat kepercayaan 95\% $(\alpha=0,05)$ menunjukkan bahwa kadar karbohidrat pada tiap-tiap taraf perlakuan memberikan perbedaan yang tidak signifikan $(\mathrm{p}=$ 0.614) terhadap kadar karbohidrat MP-ASI Bubuk Instan. Hal ini berarti kadar karbohidrat MP-ASI Bubuk Instan tiap taraf perlakuan relatif sama.

\section{Kadar Gula (Sukrosa)}

Kadar gula (sukrosa) MP-ASI Bubuk Instan berkisar antara 10,45 - 12,79 g/100 g. Kadar sukrosa yang paling rendah adalah kadar sukrosa pada formula $\mathrm{F} 1$, yaitu $10,45 \mathrm{~g}$ dan yang tertinggi adalah pada formula F7, yaitu sebesar $12,79 \mathrm{~g}$.

Berikut adalah nilai rata-rata kadar gula (sukrosa) MP-ASI Bubuk Instan dapat dilihat pada Gambar 9.

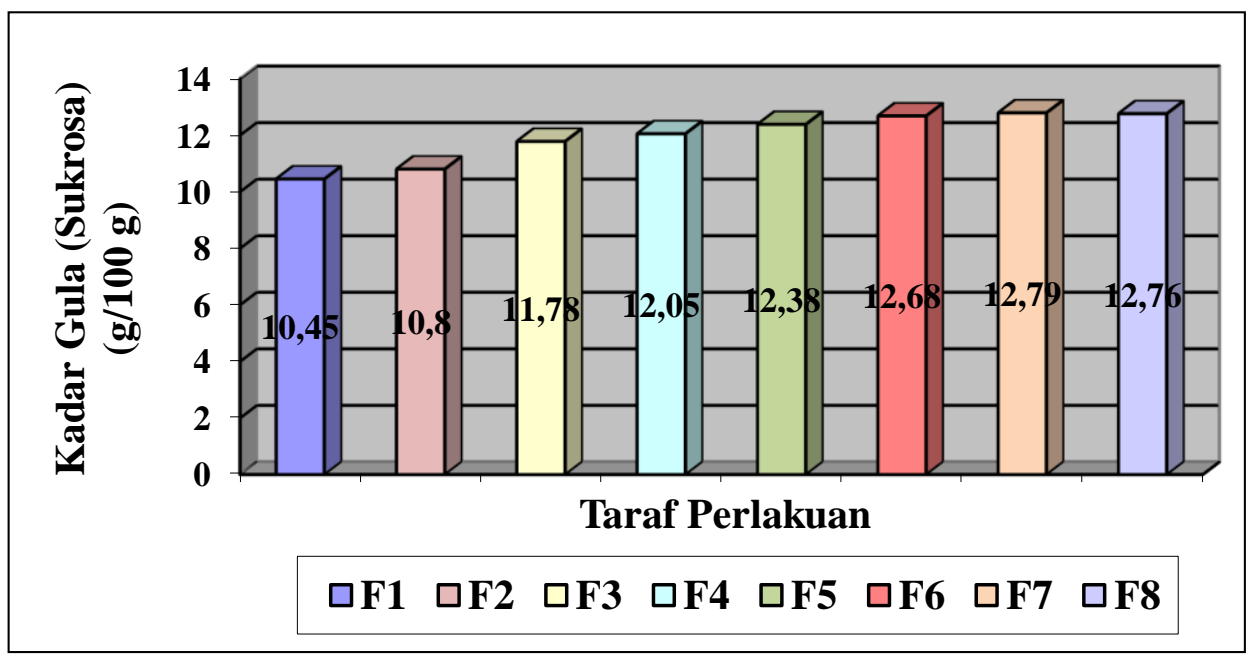

Gambar 9. Diagram Batang Kadar Gula (Sukrosa) MP-ASI Bubuk Instan Tepung Kecambah Kedelai Dan Tepung Ikan Tuna 

Uji normalitas menunjukkan bahwa data kadar sukrosa MP-ASI Bubuk Instan tidak terdistribusi normal (sign $<0,05$ ) sehingga diuji dengan analisis statistik Kruskal Wallis dengan tingkat kepercayaan $95 \%$. Hasil analisis statistik Kruskal Wallis menunjukkan bahwa proporsi tepung kecambah kedelai memberikan pengaruh yang tidak signifikan $(\mathrm{p}=0,284)$ terhadap kadar sukrosa MP-ASI Bubuk Instan. Hal ini berarti kadar sukrosa MP-ASI Bubuk Instan tiap taraf perlakuan relatif sama.

\section{Makanan Pendamping ASI Yang Memenuhi Persyaratan}

Langkah dalam penentuan MP-

ASI Bubuk Instan yang memenuhi persyaratan dapat dilihat pada perincian Lampiran 24. MPASI Bubuk Instan yang memiliki kandungan gizi dan nilai energi yang setara dan memenuhi dari persyaratan yang disyaratkan dalam KEPMENKES RI nomor 224/Menkes/SK/II/2007 tentang spesifikasi teknis MP-ASI yaitu MP-ASI Bubuk Instan dengan taraf perlakuan F1, F2, F3, F4, F5, F6. Namun untuk menentukan nilai energi dan zat gizi per takaran saji serta kontribusi MP-ASI terhadap Angka Kecukupan Gizi (AKG) bayi usia 6-8 bulan tidak dapat ditentukan dikarenakan dari enam formulasi yang ada, pada setiap formulasinya tidak semua komposisi kandungan gizi dan nilai energinya memenuhi persyaratan yang tercantum dalam KEPMENKES RI nomor 224/Menkes/SK/II/2007 tentang spesifikasi teknis MP-ASI. Hal ini dapat diketahui karena formulasi MP-ASI FI dengan proporsi tepung kecambah kedelai dan tepung ikan tuna 15\%: $85 \%$ dan F2 dengan proporsi 25\%: $75 \%$ memiliki kadar air, kadar abu, kadar protein, kadar karbohidrat, kadar gula (sukrosa) dan nilai energi telah memenuhi persyaratan yang tercantum dalam KEPMENKES RI nomor 224/Menkes/SK/II/2007 tentang spesifikasi teknis MP-ASI, namun untuk kadar lemaknya tidak memenuhi, sedangkan untuk perlakuan F3 (35\% : 65\%), F4 (45\% : 55\%), F5 (55\% :

5. MP-ASI diantara delapan formulasi yang ada.
45\%), dan F6 (65\% : 35\%) dari segi kadar air, kadar abu, kadar protein, kadar lemak, kadar karbohidrat, kadar gula (sukrosa) juga telah memenuhi persyaratan yang tercantum dalam KEPMENKES RI nomor 224/Menkes/SK/II/2007 tentang spesifikasi teknis MP-ASI, namun untuk nilai energi tidak sesuai dengan persyaratan.

\section{KESIMPULAN}

1. Ada perbedaan yang signifikan pada MPASI Bubuk Instan yang terbuat dari tepung kecambah kedelai dan tepung ikan tuna berdasarkan hasil analisa kadar abu, protein dan lemak serta adanya perbedaan yang tidak signifikan untuk kadar air, karbohidrat, serat kasar dan gula (sukrosa) MP-ASI Bubuk Instan.

2. Ada perbedaan yang signifikan pada MPASI Bubuk Instan yang terbuat dari tepung kecambah kedelai dan tepung ikan tuna untuk nilai energi MP-ASI Bubuk Instan yaitu semakin besar proporsi tepung kecambah kedelai maka nilai energi MPASI Bubuk Instan semakin meningkat.

3. Ada perbedaan formulasi tepung kecambah kedelai dan tepung ikan tuna sebagai MPASI Bubuk Instan yang sesuai dengan kebutuhan bayi pada usia 6-8 bulan yaitu semakin besar proporsi tepung kecambah kedelai maka kadar abu, lemak dan nilai energi semakin meningkat, sedangkan semakin tinggi proporsi tepung ikan tuna maka kadar protein dalam formula MP-ASI Bubuk Instan juga semakin meningkat secara signifikan.

4. Berdasarkan hasil analisa kandungan gizi dan nilai energi dapat disimpulkan bahwa MP-ASI Bubuk Instan dengan proporsi F1 (15\%: $85 \%), \mathrm{F} 2$ (25\%: $75 \%), \mathrm{F} 3$ (35\%: $65 \%), \mathrm{F} 4(45 \%: 55 \%), \mathrm{F} 5(55 \%: 45 \%)$ dan F6 $(65 \%: 35 \%)$ merupakan formulasi yang memenuhi 


\section{DAFTAR PUSTAKA}

Affiano,

I.

2010

(http://repository.ipb.ac.id/bitstream/ handle/123456789/54251/BAB\%20II \%20Tinjauan\%20Pustaka.pdf).

Tinjauan Pustaka. Bogor: Institut Pertanian Bogor. Diakses 17 Juni 2013.

Almatsier, S. 2001. Prinsip Dasar Ilmu Gizi. Jakarta: PT. Gramedia Pustaka Utama.

Astawan, M. 2004. Sehat Bersama Aneka Serat Pangan Alami. Solo: Tiga Serangkai.

Badan Standarisasi Nasional. 2005. Makanan Pendamping Air Susu Ibu (MP-ASI) Bagian 1: Bubuk Instan. Jakarta: Badan Standarisasi Nasional. (http://www.bsn.go.id.html). Diakses 21 September 2012.

Departemen Kesehatan. 2007. Keputusan Menteri Kesehatan Republik Indonesia Nomor 224/Menkes/SK/II/2007 tentang Spesifikasi Teknis Makanan Pendamping Air Susu Ibu (MP-ASI). (http://www. gizi.depkes.go.id/wpcontent/.../SK-Menkes-Spek-MP-

$\begin{array}{lll}\text { ASI-2007.pdf). Diakses } & 21\end{array}$ September 2012.

Deputi3. 2009a. Gizi Buruk di Indonesia. (http://data.menkokesra.go.id/content /gizi-buruk-di-indonesia). Diakses 07 Juli 2012.

Deputi3. 2009 ${ }^{\mathrm{b}}$. Gizi Buruk di Indonesia. (http://data.menkokesra.go.id/sites/de fault/files/gizi\%20buruk.pdf).

Diakses 07 Juli 2012.

Dewi, S. K. 2008. Pembuatan Produk Nasi Singkong Instan Berbasis Fermented Cassava Flour Sebagai Bahan Pangan Pokok Alternatif. Skripsi. Bogor: Departemen Ilmu Dan Teknologi Pangan, Fakultas Teknologi Pertanian, Institut Pertanian Bogor. 